\title{
INTRAEPITHELIAL FLAGELLA IN THE MEDUSA OF AURELIA AURITA (L.)
}

AUTHOR(S):

Chapman, D. M.; James, R.

\section{CITATION:}

Chapman, D. M.... [et al]. INTRAEPITHELIAL FLAGELLA IN THE MEDUSA OF AURELIA AURITA (L.). PUBLICATIONS OF THE SETO MARINE BIOLOGICAL LABORATORY 1973, 20: $731-743$

\section{ISSUE DATE:}

\section{3-12-19}

URL:

http://hdl.handle.net/2433/175746

RIGHT: 


\title{
INTRAEPITHELIAL FLAGELLA IN THE MEDUSA OF AURELIA AURITA (L.)
}

\author{
D. M. CHAPMAN and R. JAMES \\ Department of Anatomy and Electron Microscope Unit \\ Faculty of Medicine, Dalhousic University \\ Halifax, N.S., Canada
}

With 12 Text-figures

\begin{abstract}
Each superficial cell of the flagellated neuroepithelium of the subumbrellar pit of the medusa of Aurelia aurita sends out a basal neurite which turns through one right angle to join other neurites in a well aligned neurite layer next to the mesoglea. In with the neurites are many flagella whose cells of origin are submerged neuroepithelial cells. Because both neurites and flagella are the same diameter and because the flagellar microtubules tend to become separated in such a way as to resemble neurotubules, it was suspected that perhaps flagella could transform into neurites along their course. The evidence was weighed and found wanting mainly because the flagellar origin is blocked by a diaphragm and constriction of the plasma membrane thus preventing the egress of soma-produced granular vesicles and mitochondria which are cytoplasmic features confined to neurites.
\end{abstract}

\section{Introduction}

Cilia are usually found beating on the surface of epithelia or else they are nonmotile and modified to form sensory structures. There are many instances in the mammals, however, where there seems to be no adaptive significance to some cilia which sprout in confines where they cannot beat and where they are unlikely to be sensory structures.

The terminology for ciliary fine structure is that of Afzelius (1959) with the further elaborations of WARNER (1970).

There is some understandable looseness in the usage of the words cilium and flagellum. The distinction is not to be made on the fine structure (which is the same) or the number per cell (which in both cases may be one or more). The difference is functional and relates to the manner of movement (Prosser \& Brown, 1961). First of all we can eliminate bacterial flagella which are altogether different. Except for spermatozoa, vertebrates have cilia whether there is one or more per cell and whether or not they can beat. Certain Protozoa have one or two flagella but some have many uniformly distributed over the surface. By tradition the Cnidaria are said to have flagella but the only observation we know concerning their movement is RoBson's (1957) who found the single flagellum beating like a cilium when it was beating quickly 
but as it slowed down, it undulated like a flagellum. Up to eight flagella have been reported springing from the same spot on digestive cells in hydra (LENTZ, 1966).

Sometimes cilia of vertebrates are found in lumena such as the antrum of an ovarian follicle (MотTA et al., 1971) or the lumen of an endocrine follicle (CARPENTER, 1971). Sometimes cilia grow into solid cellular masses belonging to the various tissue classes. For epithelia we can cite the anterior pituitary (CARPENTER, 1971), parathyroid (POLYZONIS, 1970), adrenal cortex (WHEATLEY, 1967) and basal layers of the epidermis (WiLson \& MCWhorter, 1963). For nervous and related tissue, AdAmo (1971) cites examples for neurosecretory, glial, Schwann and neuronal cells. For muscle tissue we cite: heart myoblasts (RASH et al., 1969) and smooth muscle (Sorokin, 1962). For connective tissue: splenic reticular cells (BARI \& SORENSON, 1965), fibroblasts (Sorokin, 1962) and melanocytes (KLUG, 1971 and VRABEC, 1971).

A reference to an invertebrate instance concerns the chondrocytes from the squid's head cartilage; here the cilium is embedded in the matrix (Philpott \& Person, 1970).

The functional significance of these submerged cilia belongs to the realm of speculation (see BARI \& Sorenson, 1965 and BoQuist, 1968). Some workers have proposed a motor function for these cramped cilia in that the feeble twitchings might stir up the stagnant intercellular fluid (Coupland, 1965) or, in the brain, alter the anatomical relationship hence the physiology of neighboring cells (ADAMo, 1970). Partly because vertebrates have static cilia employed as sensory receptors (labyrinth and photoreceptors) other workers (MUNGER, 1958 and BARNES, 1961) guessed that the cilia in endocrine glands might be chemoreceptors especially since chemical sensitivity is an important property of endocrine cells. Many workers have probably felt (but were afraid to state) that there is no functional significance to most of these cilia and that their inappropriate formation is something that is easily triggered in many cells. DAHL (1963) doubts that the $8+1$ cilia in brain neurones are of any use to the neurones.

RASH et al. (1969) conclude from a review of the literature and their own work on differentiating tissues that most definitive vertebrate cells either have one or more cilia or have had one just before the final stages of differentiation. This is probably so and makes further reports of such occurrences trivial. Their ideas on the presence of cilia during development constitute the most worthwhile speculation. These workers recall the old theory of HENNEGUY and LENHOSSÉK relating to the similarity between centrioles and basal bodies and how it ties in with recent observations. SOROKIN (1962), MILHAUd \& PAPPAS (1968) and RASH et al. (1969) noticed that primitive and differentiating cells were in either one of two states -an interphase state with a cilium or a mitotic state lacking a cilium. One state would favour the basal body and cilium formation while the other state would favour the centrioles and spindle formation. In both cases a $9+0$ body and microtubules are involved. ARCHER \& WHEATLEY (1971) express the same idea by saying that the "disappearance of primary cilia from cells entering mitosis is a general phenomenon of mammalian cells". These 
authors dismiss the interesting idea that the ciliary tubulin is used to form the mitotic spindle on the grounds that they know of other examples of cells lacking cilia which readily undergo mitosis. We do not see why both mechanisms might not exist in different cells. Expressed slightly differently, these seemingly inappropriate cilia would constitute a reservoir of protein for the mitotic spindle. A corresponding reservoir in some higher plants could be the cortical microtubules which disappear the same time as the mitotic spindle is being assembles (LEDBETTER, 1967). According to Fulton et al. (1971) the microtubular proteins in both spindle and ciliary axoneme are similar so that the interconversion is at least a possibility.

A differentiated cell would have several choices: to have many cilia at a free surface, to retain a cilium embedded among other cells or finally to store the tubulin protein in the cytoplasm or lose it altogether.

Mammalian subsurface cilia often depart from the normal $9+2$ array. The central pair can be lacking to give a $9+0$ arrangement or sometimes one of the outer doublets moves to the vacant center to give $8+1$ (Polyzonis, 1970). Even a $7+1$ variety has been reported by ADAmo (1971) and Coupland (1965) found $6+2$ types and $8+2$ types. The hippocampus which normally has $8+1$ cilia (DAHL. 1963), produces many $9+2$ cilia after treatment with pargyline, a monoamine oxidase inhibitor (MILHAUd \& PAPPAS, 1968).

It should be noted, however, that even the non-embedded type of cilia can show departures from the usual $9+2$ array (Afzelius, 1963).

Gibbons $(1965,1967)$ localized the ATP'ase activity to the dynein arms on the A-microtubule of the doublet and because ATP allows glycerin extracted cilia to beat (see BRoKAw, 1968), it might be thought that the presence of these arms would tell if the cilium were motile. The workers on intraepithelial cilia do not mention these arms and their photographs are too unclear to ascertain this feature on the doublets. A lack of dynein arms most likely means the axoneme cannot beat because the lateralline sense cells of a dogfish each has a non-motile cilium lacking arms (ROBERTS \& RYAN, 1971). The $9+0$ cilia in a presumed ctenophore photoreceptor also lack dynein (HorridGe, 1964). The possession of dynein arms, on the other hand, does not necessarily mean the axoneme is motile because the non-motile cilium of a utricular sensory cell of a teleost has arms (FLOCK \& DUVALL, 1965) as does the eye of Bougainvillia, a hydromedusa (SINGLA, 1972, p. 49).

CHAPMAN (in press) mentioned the high incidence of intraepithelial flagella in a cnidarian and wondered whether there was some significance to this finding as there was evidence indicating a similarity between neurites and transformed flagella. This paper pursues this idea more fully.

SLIFER \& SEKHON (1969) have noted the same transformation phenomenon in a sense cell from an insect. In this case a short dendrite springs from the bipolar sense cell at the cuticle. After a short distance two axially aligned basal bodies are found, the distal one of which is in continuity with a short $9+0$ ciliary microtubular array 
which transforms into simple microtubules which seem to bifurcate thus doubling their numbers at intervals.

\section{Materials and Methods}

Marginal sensory complexes of the scyphomedusa, Aurelia aurita from Bedford Basin, Halifax, Nova Scotia were fixed for $1 \mathrm{~h}$ in the following fixative:

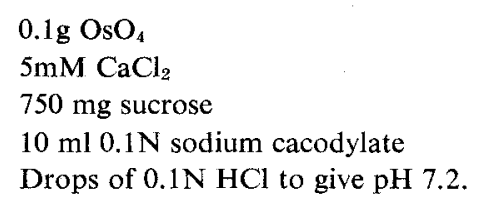

The tissue was dehydrated in an ethanol series, embedded in Araldite or styrenemethacrylate (KUSHIDA, 1961) and the sections stained in alcoholic uranium acetate (KAY, 1965; p. 262 after GibBons and Grimstone).

The great amount of dilute acid needed to bring the $\mathrm{pH}$ to 7.2 seems to have made the fixative too low osmotically because there was an abnormal separation between the inner and outer nuclear membranes.

\section{Results}

Anatomy: Fig. 1 shows how the marginal sensory complexes in Aurelia are made up of at least three neuroepithelia and two pigmented eye regions. The touch-plate has static flagella and, no doubt, is involved in the appreciation of the tilt of the medusa. The sides of the rhopalium have motile flagella which send a weak current towards the two subumbrellar pits which therefore might be chemosensory regions (see Chapman's description in Russell, 1970, p. 145). These pits are in the form of slender blunt cones.

Microanatomy (See Fig. 2): Except mainly for a few mucous cells, the epithelium of the subumbrellar pits is composed of flagellated columnar cells (Figs. 3, 10) having a basal neurite which is directed toward the mesoglea - but before reaching the mesoglea, it gradually turns horizontally to run parallel to this layer. Between the horizontal neurite layer and the mesoglea are large clear cytoplasmic processes (Fig. 6) belonging to an unknown parent cell. In sections showing the horizontal neurites in transverse section, it is often observed that the neurites are gathered into bundles which are marked off by vertical cytoplasmic processes, once again belonging to an unknown cell.

The flagellated cell is rather like the touch-plate cell (CHAPMAN, in press and Chapman's Fig. 3 in Russell, 1970, p. 6) except that the collar around the flagellar base is weakly developed in the pit region.

In some regions the columnar flagellated cells are quite regular and constitute a single layer; in most regions, however, there is some stratification. The most interesting complication has to do with flagellated cells within the horizontal neurite layer. 


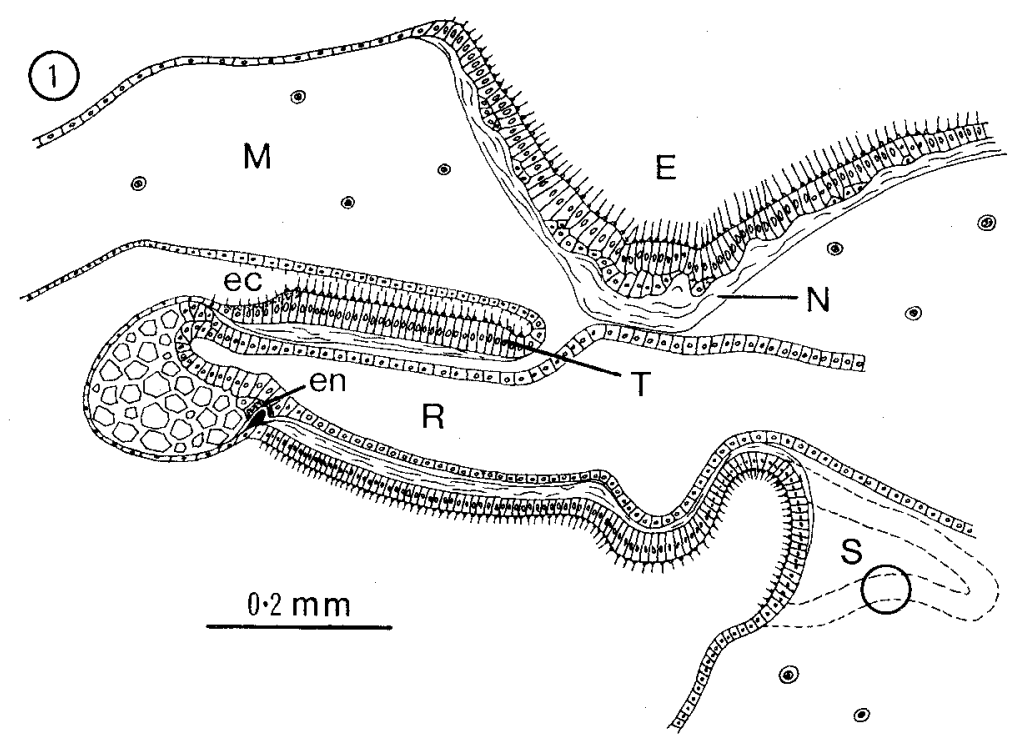

Fig. 1. Drawing of a radial section through a marginal sensory complex in the medusa of Aurelia aurita. The subumbrellar pit (S) is stippled in outline because each member of the pair is just to one side of the mid-line. The neuroepithelia have an underlying neurite layer e.g. (N). E, exumbrellar pit; ec, ectodermal eye; en, endodermal eye; M, mesoglea; $N$, neurite layer; $R$, lumen of rhopalium; $S$, subumbrellar pit; $T$, touchplate.

Here isolated cells are clearly seen because of the surrounding neurites. These cells seem to be oriented randomly and hence send their flagellum out in any direction at first but soon the flagellum turns to join the neurites and other flagella in their horizontal alignment. Fig. 7 shows a cell with a flagellum at one end and a neurite at the other.

Most of the intraepithelial flagella, however, come from cells just below the epithelial zone. Because no cell has ever been seen in this tissue with a flagellum at both poles, cells sending flagella basally are most likely up-side-down. Whether a neurite was present at the other end could not be determined. Once again the basally directed flagella turn to become oriented with the horizontal neurite layer.

This horizontal layer contains two types of cytoplasmic processes of similar diameter (Fig. 6). There are the neurites which contain neurotubules, granular vesicles and occasional mitochondria. Their diameters range from $0.25-0.80 \mu \mathrm{m}$ with an approximate average of $0.4 \mu \mathrm{m}$. The other type is the flagellum of rather uniform diameter $(0.4 \mu \mathrm{m})$ and these seldom contain anything but the usual $9+2$ system of microtubules - which, as will be shown, can be highly modified.

The point of interest in this paper has to do with the transitional forms linking the quite different flagellar and neurite profiles. Some examples of break-up of flagella can be seen in Fig. 6 but it is in Fig. 9 where this phenomenon is best illustrated. In 
Fig. 9a the axoneme is intact but there is some uncharacteristic membranous matter enclosed by the plasma membrane. In Fig. $9 \mathrm{~b}$ the axoneme has opened out. (Sometimes this may happen in a sine wave configuration.) Fig. 9c shows a centrifugal

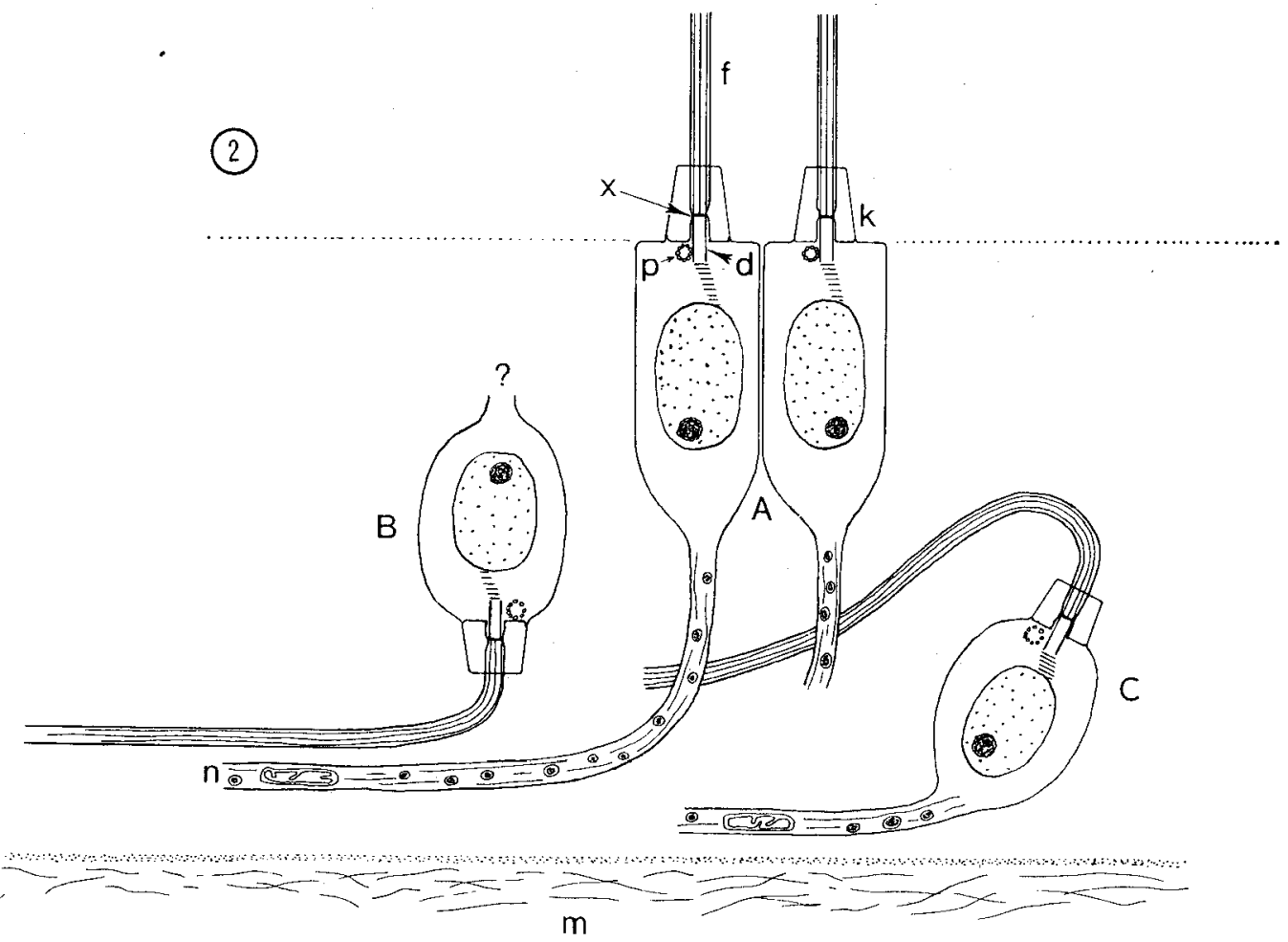

Fig. 2. Diagram of the neuroepithelium of the subumbrellar sensory pit. The usual arrangement is shown at A; sometimes the submerged cells may be upside-down and near the surface (B) or else the cell is deeper and at any orientation (C). Neurites were not found in the type B cell but they probably exist (hence the question mark). $\mathrm{d}$, distal basal body; $f$, flagellum; $k$, collar at base of flagellum; $m$, mesoglea; $n$, neurite; $p$, proximal basal body; $x$, constriction of the plasma membrane at the junction of $d$ and $\mathrm{f}$.

Figs. 3-12. Unless otherwise stated the tissue was embedded in Araldite and stained with uranium and was taken from the subumbrellar pit. The markers in Figs. 3-11 are measured in nicrometers.

Fig. 3. Horizontal section of the pit's lumen-but not quite through the diameter. The lumen contains flagella and the collars surrounding flagella. The superficial part of the epithelium contains golgi bodies and granules; a little deeper is the nuclear zone.

Fig. 4. A longitudinal section of a flagellum and neurites in the deep zone of the epithelium. Note the connections between the neurotubules and the vesicles at the arrow heads.

Fig. 5. A longitudinal neurite bloated with granular vesicles and a reticulum (exumbrellar pit). $\mathrm{C}$, collar; F, flagellum; L, lumen; $\mathrm{N}$, neurite; $\mathrm{Nt}$, neurotubule; $\mathrm{Nu}$, nucleus; $\mathrm{R}$, reticulum; V, vesicles, mainly granular. 


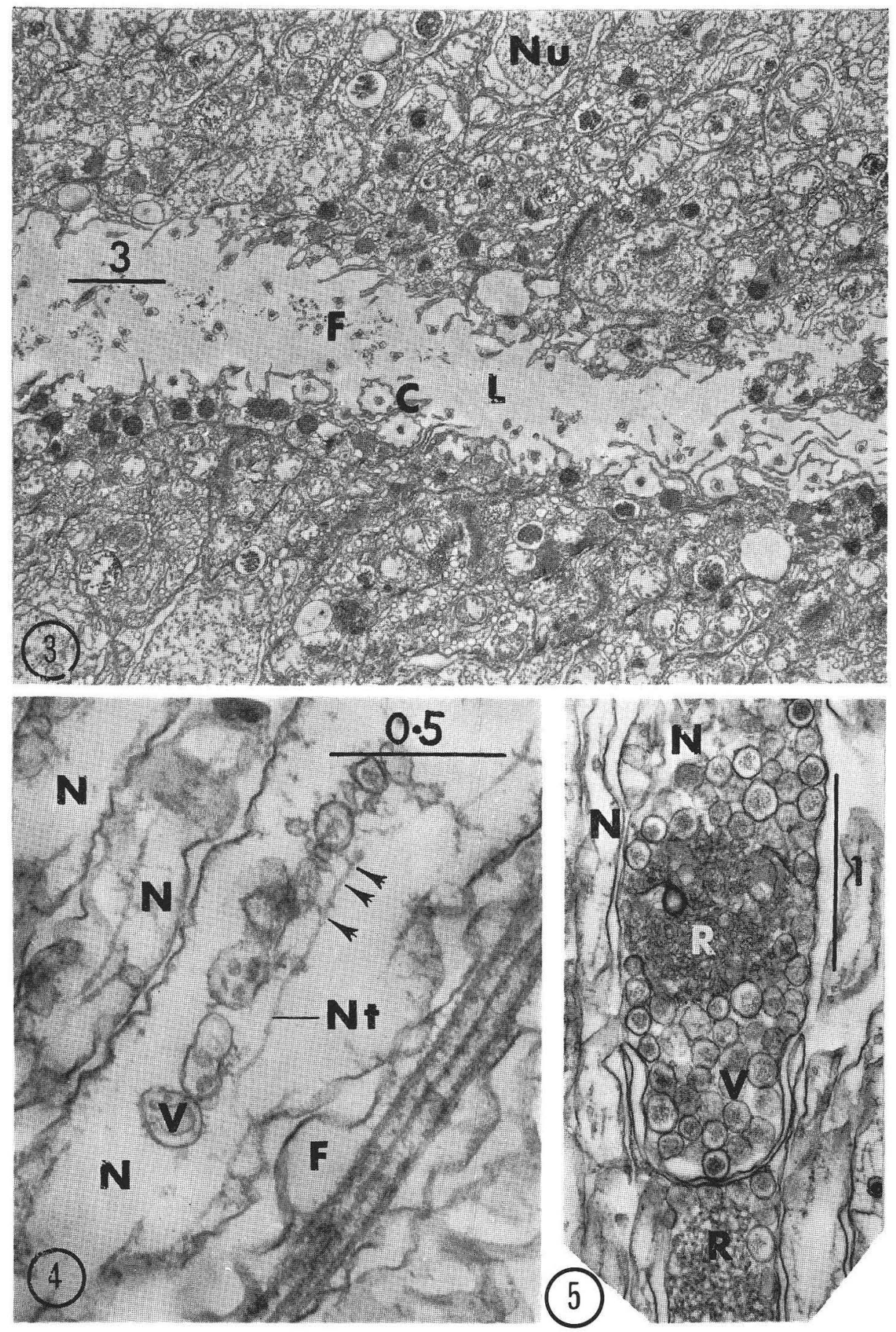



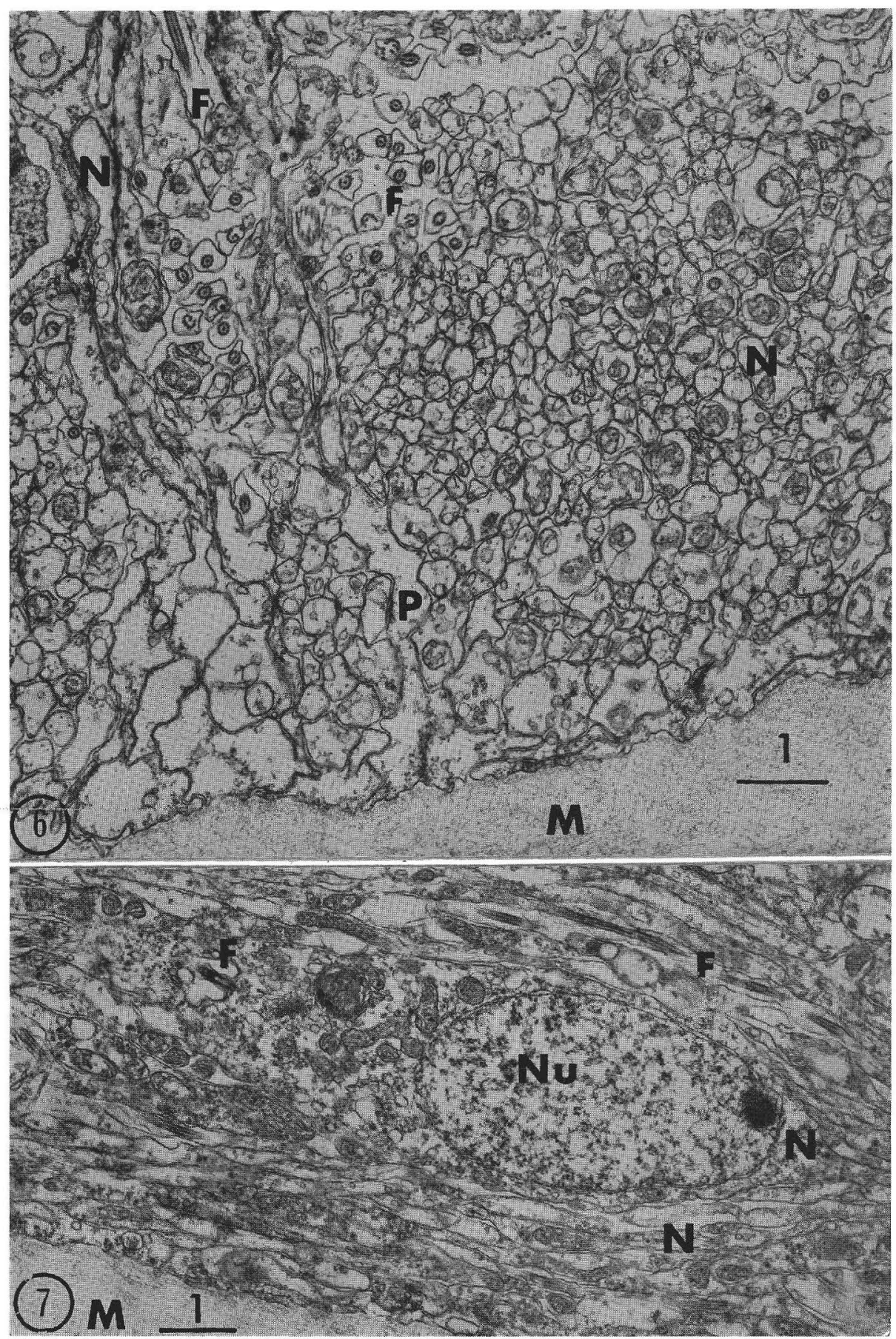
drift of the outer microtubules, some of which are now single. Fig. 12 shows this drift and it can be seen that the dynein arms are still present. Fig. $9 \mathrm{~d}$ is still recognizable as an axoneme but Fig. 9e is doubtful and one can no longer tell if one is dealing with single axonemal microtubules or with neurotubules. (An unequivocal difference between transverse sections of neurotubules and single flagellar microtubules could not be made out on the basis of diameter or the present electron staining characteristics; however, in longitudinal sections, the neurotubule is fainter, less straight and perhaps slightly narrower (Fig. 4)). Fig. 9f is rather like Fig. 9e except that the former is wider and contains a granular vesicle, hence resembling a neurite.

It should be stressed that flagella rarely contain vesicles in this material but Figs. 9a \& 8 are exceptions. A stricter rule is that flagella do not contain granular vesicles.

Longitudinal sections of intraepithelial flagella were searched for examples of these transitional forms but it was too difficult to find flagella running in the plane of section for sufficient distances to note these changes.

Twice in this study we noticed a fiagellum having punctured another cell -at least this is the interpretation we put on Fig. 11.

Fig. 4 shows an interesting feature recently described by SмIтH (1971) for a vertebrate neurone. This is a short connection between a neurotubule and neighboring vesicles.

Worth recording is the observation that some neurites of the similar exumbrellar pit were packed with granular vesicles and a reticular formation (Fig. 5). It is suggested that the reticular matter represents broken down and reconstituted remnants of discharged granular vesicles.

\section{Discussion}

The abundance of intraepithelial flagella is probably brought about by a slight stratification of flagellated cells caused by the cramping during the formation of the narrow cones which constitute the subumbrellar pits. If these cells are obliged in their genetic program to form a flagellum then they do so whether on the surface or submerged. The touch-plate being less cramped has only a few intraepithelial flagella. Perhaps there is no deeper significance than this.

At first, however, we wondered whether the flagella were transforming into neurites and, furthermore, we conjectured that the phylogenetic origin of neurites was to be sought along these lines. The evidence in favour of this is now summarized.

Both flagella and neurites are about the same diameter and are aligned in the

Fig. 6. Transverse section of the deep zone of the pit. Flagella in various states of disarray are present at the top. Deeper are the neutites along with some presumed partitioning processes.

Fig. 7. A longitudinal section of a submerged epithelial neurone. Note the flagellum at one end and the neurite at the other. Styrene-methacrylate.

$\mathrm{F}$, flagellum; $\mathrm{M}$, mesoglea; $\mathrm{N}$, neurite; $\mathrm{Nu}$, nucleus; $\mathrm{P}$, presumed partitioning process. 
D.M. Chapman and R. James
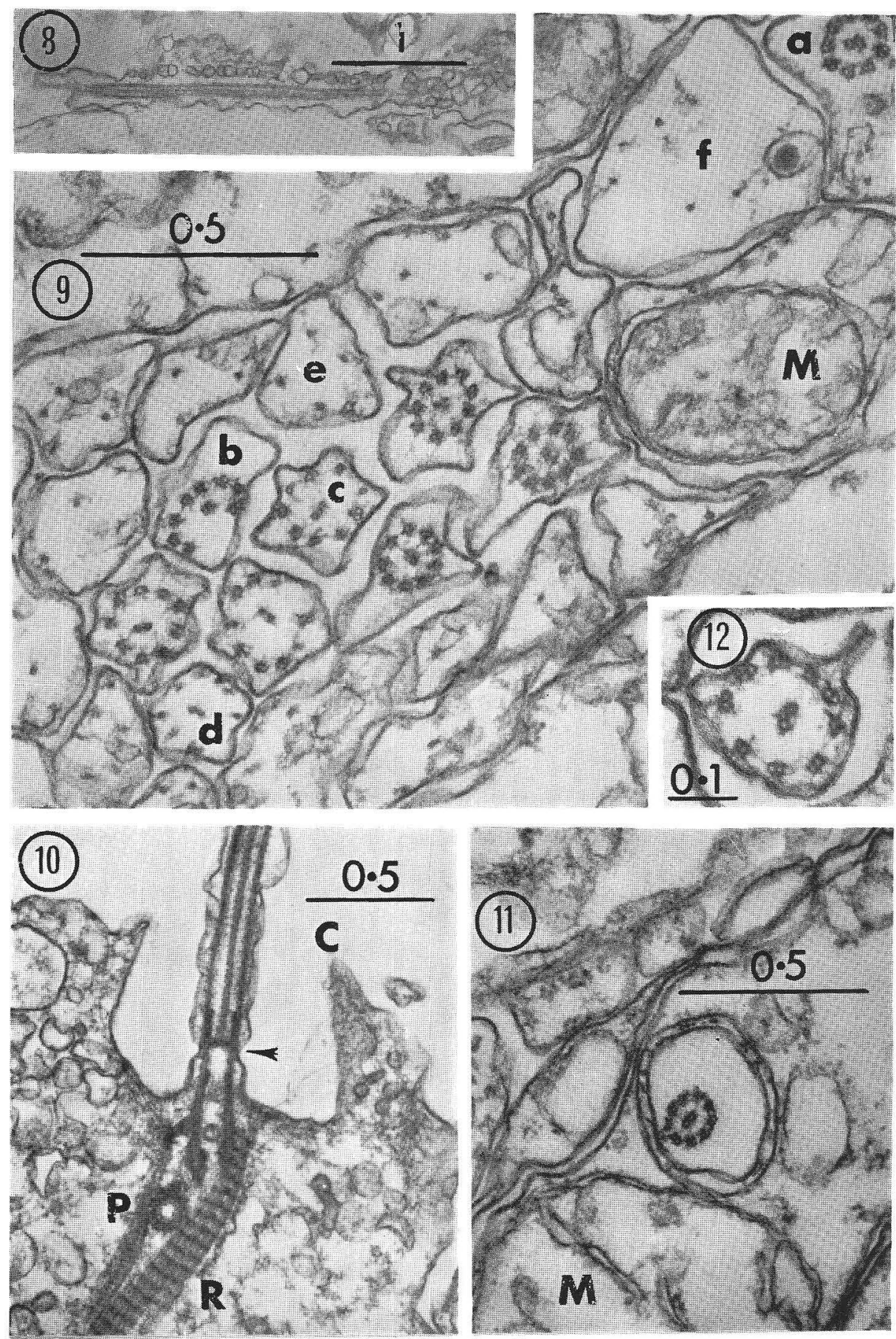
same orientation. Both contain microtubules and both can puncture other cells (CHAPMAN, in press). Because the intraepithelial flagella are usually found superficial to the neurite layer and because the flagellar axonemes break up, presumably distally, it could be inferred that as a flagellum extended distally and deeper, it would give rise to a neurite.

The evidence against this interesting view is, however, stronger. No intraepithelial flagellum, even where the $9+2$ microtubules were breaking up, ever showed mitochondria, granular vesicles or neurotubules (that is to say, microtubules in excess of the $9+2$ ) which are all features of neurites. In longitudinal sections there was never found evidence for a flagellum transforming into a neurite but admittedly this would not be an easy thing to detect. The constriction of the flagellar membrane at the distal basal body and its transverse plate (Fig. 10) would prevent golgi-produced vesicles from entering the flagellum. Synapse-like structures between flagella were never observed but then again synapses were only rarely observed between neurites. The alignment of the intraepithelial flagella with the neurites is explained on the basis that this would be the path of least resistance to a growing flagellum.

The direction of neurite growth would in the first instance undoubtedly be directed chemotactically but electron photomicrographs showed flagella bending in either direction when they joined the aligned neurites. Another proof that flagella grow in either direction derives from observing the orientation of the dynein arms of a cluster of flagellar cross-sections. One can deduce the direction of a flagellum from the direction these arms point (GiBBons, 1961). Since in any cluster both arm directions are noted in different flagella, we infer that flagella grow in either direction. (However, in any cluster the direction is usually the same.)

The normal $9+2$ microtubules, although separate, seem to be firmly bound in an exact array which is not often disturbed even with poor fixation or removal of the plasma membrane (GibBons, 1965; Hookes et al., 1967, p. 119). Nevertheless, this study has shown many instances where the array opens out or is somewhat scattered. AfZelius (1963) noted an occasional opening out of the peripheral 9 in sea urchin sperm.

The presence of peripheral single microtubules in the axoneme is characteristic

Fig. 8. Longitudinal section of a flagellum containing agranular vesicles.

Fig. 9. A view showing transitions between flagellum and neurite forms.

a, typical axoneme but plasma membrane enclosing some uncharacteristic matter. b, one sector of the axoneme has opened out. c, centrifugal displacement of the peripheral microtubules, some of which are single. $\mathrm{d}$, like $\mathrm{c}$ only more extreme. $\mathrm{e}$, difficult profile to identify. $\mathrm{f}$, probably a neurite because of the granular vesicle and great width.

Fig. 10. Apical region of the neurocpithelial cell. The collar is thicker than normal. Note the constriction at the arrow head.

Fig. 11. A flagellum passing through another cell.

Fig. 12. Centrifugal displacement of the peripheral doublets which have dynein arms. C, collar; $\mathrm{M}$, mitochondrion; $\mathrm{P}$, near proximal basal body; $\mathrm{R}$, rootlet. 
of a tip of a cilium (SATIR, 1968) but in Fig. 9c, the double and single configurations co-exist.

Vertebrates often show a deletion in the central 2 microtubules in their submerged cilia with a compensatory shift of a peripheral doublet to the center to give an $8+1$ array; however, this behavior is not noted in Aurelia.

Vertebrate submerged cilia seem to be of two sorts: one variety may spring from a basal body near the surface; or, the other may begin from a deeply situated centriole. When the latter, the cilium (axoneme plus its plasma membrane) travels a long distance from its recessed position before it reaches the surface. This means a transverse section of the intracellular part might give the impression that a cilium had punctured the cell. In Aurelia centrioles were not found and the flagella only arose from a superficial basal body. From this we infer that any intracellular profile of a flagellum means that it has punctured another cell.

\section{REFERENCES}

Adamo, N. J., 1971. Cilia in the accessory hyperstriatum of the domestic fowl. Z. Zellforsch. 115, 335-340.

Afzelius, B. A., 1959. Electron microscopy of the sperm tail. J. biophys. biochem. Cytol. 5, 269-278.

Afzelrus, B. A., 1963. Cilia and flagella that do not conform to the $9+2$ pattern. J. Ultrastruct. Res. 9, 381-392.

Archer, F. L. \& Wheatley, D. N., 1971. Cilia in cell-cultured fibroblasts II. Incidence in mitotic and post-mitotic BHK 21/C13 fibroblasts. J. Anat. 109, 277-292.

Bari, W. A. \& Sorenson, G. D., 1965. Ciliated cells in the spleen of adult rats. Anat, Rec. 152. 481485.

BARnES, B. G., 1961. Ciliated secretory cells in the pars distalis of the mouse hypophysis. J. Ultrastruct. Res. 5, 453-467.

Boquist, L., 1968. Cilia in normal and regenerating islet tissue. Z. Zellforsch. 89, 519-532.

Brokaw, C. J., 1968. Mechanisms of sperm movement. In "Aspects of Cell Motility". Ed. by P.L. Miller, Symp. Soc. Exp. Biol. 22, 101-116. Cambridge University Press, Cambridge.

Chapman, D. M., (in press). Cnidarian histology. In "Outlooks in Coelenterate Biology." Ed.by H. Lenhoff and L. Muscatine. Academic Press, New York.

Carpenter, E., 1971. Fine structure of rat pituitary cilia. Anat. Rec. 169, 637-650.

Coupland, R. E., 1965. Electron microscopic observations on the structure of the rat adrenal medulla. J. Anat. 99, 231-254.

DAHL, H. A. 1963. Fine structure of cilia in rat cerebral cortex. Z. Zellforsch. 60, 369-386.

Flock, A. \& Duvall, A. J., 1965. The ultrastructure of the kinocilium of the sensory cells in the inner ear and lateral line organs. J. Cell Biol. 25, 1-8.

Fulton, C., Kane, R. E. \& Stephens, R. E., 1971. Serological similarity of flagellar and mitotic microtubules. J. Cell Biol. 50, 762-773.

GrbBons, I. R., 1961. The relationship between the fine structure and direction of beat in gill cilia of a lamellibranch mollusc. J. biophysic. biochem. Cytol. 11, 179-205.

GrbBons, I. R., 1965. Chemical dissection of cilia. Arch. Biol. (Liège) 76, 317-352.

GibBons, I. R., 1967. The structure and composition of cilia. In "Formation and Fate of Cell Organelles". Ed. by K. B. WArren. Symp. Int. Soc. Cell Biol. 6, 99-113. Academic Press, New York/London.

Hookes, D. E., Randall, Sir J., \& Hopkins, J. M., 1967. Problems of morphopoiesis and macromolecular structure in cilia. ibid., pp. 115-173. 
Horridge G. A., 1964. Presumed photoreceptive cilia in a ctenophore. Quart. J. micr. Sci. 105, 311317.

KaY, D. H. (Editor) 1965. Techniques for Electron Microscopy. Blackwell Scientific Publications, Oxford.

KLuG, H., 1971. Über die Bildung rudimentärer Zilien bei Melanozyten. Experientia 27, 83-84.

KushiDA, H., 1961. A styrene-methacrylate resin embedding method for ultrathin sectioning. $J$. Electron Micros. 10, 16-19.

LedBetTer, M. C., 1967. The disposition of microtubules in plant cells during interphase and mitosis. In "Formation and Fate of Cell Organelles". Ed. by K. B. WARren. Symp. Int. Soc. Cell Biol. 6, 55-70. Academic Press, New York/London.

Lentz, T. L., 1966. The Cell Biology of Hydra. North Holland Publishing Co., Amsterdam.

Milhaud, M. \& Pappas, G. D., 1968. Cilia formation in adult cat brain after pargyline treatment. J. Cell Biol. 37, 599-607.

Motta, P., Takeva, Z. \& Palermo, D., 1971. On the presence of cilia in different cells of the mammalian ovary. Acta anat. 78, 591-603.

Munger, B. L., 1958. A light and electron microscopic study of cellular differentiation in the pancreatic islets of the mouse. Amer. J. Anat. 103, 275-311.

Philpott, D. E. \& Person, P., 1970. The biology of cartilage II. Invertebrate cartilages: squid head cartilage. J. Morph. 131, 417-430.

Polyzonis, M. B., 1970. Ultrastructural study of human parathyroid adenoma and the occurrence of abnormal cilia in the adenoma cells. Path. europ. 5, 454-469.

Prosser, C. L. \& Brown, F. A., 1961. Comparative Animal Physiology. W. B. Saunders, Philadelphia/London.

Rash, J. E., Ahay, J. W. \& Biesele, J. J., 1969. Cilia in cardiac differentiation. J. Ultrastruct. Res. 29, $470-484$.

Roberts, B. L. \& Ryan, K. P., 1971. The fine structure of the lateral-line sense organs of dogfish. Proc. $r$. Soc. Series B. 179, 157-169.

Robson, E. A., 1957. The structure and hydromechanics of the musculo-epithelium in Metridium. Quart. J. Microsc. Sci. 98, 265-278.

Russell, F. S., 1970. The Medusae of the British Isles. Vol. 2. Pelagic Scyphozoa with a Supplement to the First Volume on Hydromedusae. Cambridge University Press, Cambridge.

SatIR, P., 1968. Studies on cilia III. Further studies on the cilium tip and a "sliding filament" model of ciliary motility. J. Cell Biol. 39, 77-94.

Singla, C. L., 1972. Sense organs of Hydromedusae. Thesis, University of Victoria, Victoria, Canada.

Slifer, E. H. \& Sekhon, S. S., 1969. Some evidence for the continuity of ciliary fibrils and microtubules in the insect sensory dendrite. J. Cell Sci. 4, 527--540.

SMITH, D. S., 1971. On the significance of cross-bridges between microtubules and synaptic vesicles. Phil. Trans. Roy. Soc. Lond. B 261, 395-405.

SorokIN, S., 1962. Centrioles and the formation of rudimentary cilia by fibroblasts and smooth muscle cells. J. Cell Biol. 15, 363-377.

Vrabec, F., 1971. Ciliated cells of the rabbit and human iris stroma. Amer. J. Ophthal. 71, 69-74.

WARnER, F. D., 1970. New observations on flagellar fine structure. J. Cell Biol. 47, 159-182.

Wheatley, D. N., 1967. Cilia and centrioles of the rat adrenal cortex. J. Anat. (London) 101, 223237.

WiLson R. B. \& MCWhorter, C. A., 1963. Isolated flagella in human skin. Lab. Invest. 12, $242-249$. 